\title{
Seasonal constancy (summer vs. winter) of benthic size spectra in an Arctic fjord
}

\author{
Mikołaj Mazurkiewicz ${ }^{1}$ (D) Barbara Górska ${ }^{1}$ Paul E. Renaud ${ }^{2,3} \cdot$ Joanna Legeżyńska ${ }^{1}$ J Jørgen Berge ${ }^{3,4}$. \\ Maria Włodarska-Kowalczuk ${ }^{1}$
}

Received: 27 August 2018 / Revised: 17 May 2019 / Accepted: 28 May 2019 / Published online: 8 June 2019

(C) The Author(s) 2019

\begin{abstract}
Size spectra are important descriptors of community structure and can indicate changes in community functioning in response to shifts in environmental conditions. There are relatively few assessments of benthic size spectra, and most are based on summer samples alone. Processes influencing size spectra, such as recruitment and predation pressure, vary seasonally, and understanding this variation is necessary to interpret patterns in time or space. Here we compare summer and winter biomass size spectra in the central basin of Kongsfjorden (west Spitsbergen). We recorded seasonal changes in the quality of organic matter available to the benthos, indicated by higher chloroplastic pigments concentrations in surface sediments in summer, as well as in differences in total abundance and biomass of both macrofauna and meiofauna. No significant seasonal differences were documented by multiple regression models for the normalized biomass and size classes. The slope of a linear relationship between normalized biomass and size classes was $-0.54 \pm 0.02$ indicating a productive system, compared to ecosystems like estuaries. Summer-winter invariability of size spectra suggests that benthic community functioning in this Arctic fjordic system is relatively independent from the seasonality in the supply of organic matter produced in water column.
\end{abstract}

Keywords Zoobenthos $\cdot$ Meiofauna $\cdot$ Size spectra $\cdot$ Arctic winter $\cdot$ Biomass

\section{Introduction}

\section{Motivation and research objectives}

The importance of size structure for the functioning of an ecosystem was raised almost a century ago by Elton (1927) in a concept of "ecological pyramids". The focus on the

Electronic supplementary material The online version of this article (https://doi.org/10.1007/s00300-019-02515-2) contains supplementary material, which is available to authorized users.

Mikołaj Mazurkiewicz

mikolaj@iopan.pl

1 Department of Marine Ecology, Institute of Oceanology Polish Academy of Sciences, Powstańców Warszawy 55, 81-712 Sopot, Poland

2 Fram Centre for Climate and the Environment, Akvaplan-niva, 9296 Troms $\varnothing$, Norway

3 University Centre in Svalbard, 9071 Longyearbyen, Norway

4 Faculty for Biosciences, Fisheries and Economics, Department for Arctic and Marine Biology, UiT The Arctic University of Norway, 9037 Troms $\varnothing$, Norway importance of size spectra and biomass spectra as descriptive features of marine communities, however, only accelerated more than 50 years later, when Parsons (1969) and Sheldon et al. (1972) used particle size spectra to provide new insights into plankton communities functioning, and Platt and Denman (1977) published analyses including normalized size spectra. Since then, different kinds of size spectra, focused on either abundance or biomass, have been used to describe aquatic communities in freshwater (e.g., Sprules and Munawar 1986; Sprules and Goyke 1994), marine pelagic (e.g., Zhou et al. 2004; García-Comas et al. 2014) or benthic (e.g., Warwick and Clarke 1984; Quiroga et al. 2005; Kelly-Gerreyn et al. 2014) systems. However, due to some technological advantages such as automated particle counters (Laser Optical Particle Counter-LOPC, Coulter counter) or acoustic methods (Yurista et al. 2014; Kerckhove et al. 2016), and faster sample processing, pelagic size structure analyses are much more common than those focused on benthic biota. The utility of size spectra in ecological studies is quite extensive as they have been used as indicators of primary production (Sprules and Barth 2016), ecosystem disturbances and/or stability (Zhou et al. 2007), impact of 
fisheries (Boudreau and Dickie 1992), and consequences of warming or trophic transfer efficiency (Jennings et al. 2002; Binzer et al. 2016).

The seasonality of environmental parameters such as light conditions, air temperature, precipitation, meltwater discharge, iceberg impact, or ice-cover is a major regulator of Arctic marine ecosystem dynamics (Loeng et al. 2005). The winter in the Arctic is a period defined by the lack or scarcity of light, and the functioning of the marine ecosystem in December-February is shaped both by temperaturedependent (e.g., water stratification or metabolism rate) and light-dependent processes (Berge et al. 2015b). Seasonality in physical settings influences the timing and rates of primary productivity, and thus, the food supply for consumers forcing organisms to adapt to periods of lower organic matter fluxes (Pawłowska et al. 2011; Juul-Pedersen et al. 2015). However, the paradigm of dramatically lower activity of Arctic organisms during the unproductive season of polar night was recently questioned by Berge et al. (2015a). They documented intense biological activities during polar night, implying that, despite the absence of primary production, many biological processes and trophic interactions are maintained on a similar level as in other seasons, based on stored, recycled, or advected energy sources (organic carbon). It was also shown that benthic fauna from Kongsfjorden (Spitsbergen) can be very resilient to seasonal changes in food quality, thanks to the ability to utilize reworked organic material (Kędra et al. 2012). Consistently similar high standing stocks and activity of the benthic communities in all seasons on the Antarctic continental shelf have been explained by the "food bank" hypothesis (Mincks et al. 2005; Glover et al. 2008) that related low benthic seasonality to the persistent availability of labile organic carbon in sediments throughout the year. Overall the literature concerning seasonality of benthos in polar regions is not conclusive-in some cases indicating rise of oxygen uptake after the seasonal pulse of organic matter sedimentation (e.g., Rysgaard et al. 1998; Renaud et al. 2007, 2008; Link et al. 2011). Shallow water communities can exhibit seasonal variation in abundance of carnivores and opportunistic species (Kędra et al. 2011), and abundance and diversity have been shown to be related to iceberg impact and wind-driven hydrodynamic conditions (Echeverria and Paiva 2006). Pawłowska et al. (2011) showed seasonal variation of meiofaua and macrofauna standing stock and diversity in a glaciofluvial bay (Adventfjorden, Svalbard) related to temporal variability in primary production and magnitude of meltwater discharges.

Biomass size spectra proved to be useful descriptors of both: community structure and its functioning (Sprules and Barth 2016, and references therein). In the Arctic, they have been used by Soltwedel et al. (2000) to reveal a relationship between mean biomass of deep-sea nematodes and concentration of the photosynthetic pigments in sediments. Górska and Włodarska-Kowalczuk (2017) showed that food availability and disturbance may control the total bulk and size structure both in meio- and macrofauna. Most of the size structure studies have been based on materials collected in one season only (mostly summer), and the need of the recognition of the seasonal variability in environmental features (such as food supply) on the community size structure was raised by Kelly-Gerreyn et al. (2014). This is crucial to know how representative are patterns observed in summer for the year-round situation, especially in the Arctic systems which are characterized by a large seasonal variability in environmental conditions, particularly the pelagic primary production and organic matter fluxes to the sea bottom, and highly seasonal recruitment events (Kukliński et al. 2013).

In this study, we examine seasonal (summer-winter) variability in benthic (meiofauna and macrofauna) community size structure in a high Arctic fjord, which is characterized by high seasonal variability of environmental conditions. To provide background environmental and biological constrains on this variability, we recorded hydrological parameters and geochemical descriptors of organic matter content in sediments, as well as abundance and biomass and taxonomic composition of the fauna. Seasonal variability in size structure of benthic community would imply seasonal changes in organic carbon processing, nutrient fluxes as a result of trophic interactions, or recruitment events. To our knowledge, this is the first study focused on seasonal variability in benthic size structures in the Arctic.

\section{Study area}

Kongsfjorden $\left(79^{\circ} \mathrm{N}\right.$ and $\left.12^{\circ} \mathrm{E}\right)$ is a fjord on the northwest coast of Spitsbergen - the largest island of the Svalbard archipelago (Fig. 1). This $28-\mathrm{km}$-long fjord is oriented along a northwest-southeast axis, with a 10-km wide opening connecting the fjord with the Greenland Sea.

The Kongsfjorden ecosystem undergoes strong seasonal and inter-annual changes in biota functioning due to changes in hydrography, driven by impact of the West Spitsbergen Current (WSC), melting of snow and glaciers, local climate features, and global climate changes (e.g., Cottier et al. 2005; Wiencke and Hop 2016; Noufal et al. 2017). These processes are key ecological regulators as they determine timing of the spring bloom, taxonomic composition of pelagic communities, or biogenic matter fluxes (e.g., Hop et al. 2006; Hegseth and Tverberg 2013; Lalande et al. 2016).

The strength and timing of the spring phytoplankton bloom is dependent on advection of water from the WSC into the fjord. Inflows along the bottom allow for the convection and mixing, enhancing the bloom, while surface inflows can hinder water mixing and delay the bloom (Hegseth and Tverberg 2013). In summer, as a result of river runoff, precipitation, and glacier melting, a surface layer of less saline 
Fig. 1 Location of sampling stations in Kongsfjorden. Gray dots represent locations of sampling station in summer, black dotsin winter

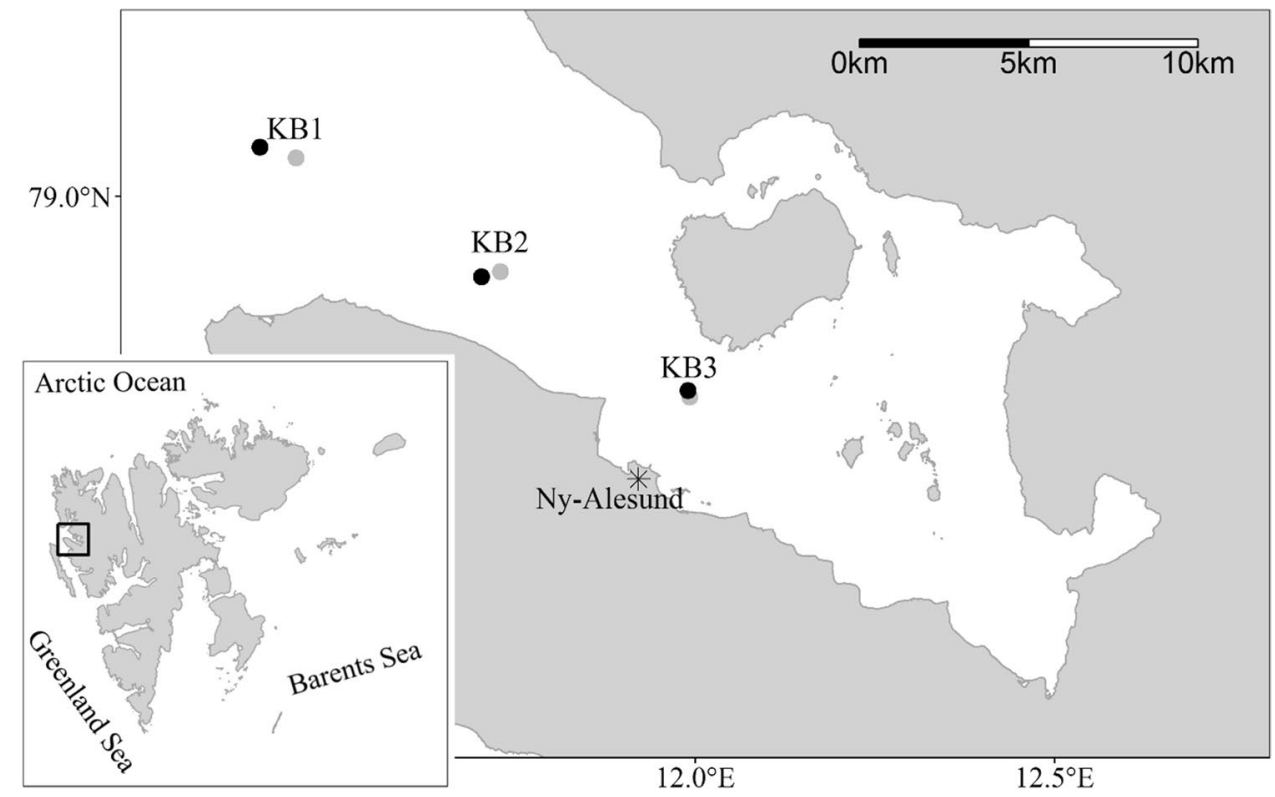

waters forms, which together with a strong subsurface intrusion of warm and more saline Atlantic waters causes strong stratification of the water column (Noufal et al. 2017). In winter, as a consequence of water cooling, the whole water column is well mixed (Noufal et al. 2017). During this time the biological activity of both autotrophs and zooplankton in the water column is very low, resulting in low organic matter fluxes to the sea bottom (Lalande et al. 2016).

\section{Materials and methods}

\section{Sampling}

Samples were collected in summer (August 2014) from r/v "Oceania" and in winter (January 2015) from r/v "Helmer Hanssen" in Kongsfjorden. Sediments, meiofauna, and macrofauna were collected at three stations located in the outer basin of the fjord at depths varying from 260 to $350 \mathrm{~m}$ (Fig. 1; Online Resources 1Table ESM1). Sampling was intended to occur at exactly the same positions in winter and summer, but due to the navigational issues the actual locations of sampling in the two seasons differed by about $450 \mathrm{~m}$ (station KB1), $390 \mathrm{~m}$ (station KB2), and $220 \mathrm{~m}$ (station KB3). Macrofauna samples (one sample per station per season) were collected with use of $0.1 \mathrm{~m}^{2}$ van Veen grab and sieved on board on a 500- $\mu \mathrm{m}$ mesh. Meiofauna samples (one sample per station per season) were collected with a plastic syringe $\left(10 \mathrm{~cm}^{2}\right.$ sampling area) inserted $10 \mathrm{~cm}$ deep into sediment collected with a box-corer. Both macrofauna and meiofauna samples were preserved in $4 \%$ formaldehyde solution in seawater. Sediment samples were collected with a Niemisto gravity corer (one sample for grain size (only in summer) and one sample for particulate organic carbon (POC) content and three replicates for photosynthetic pigments: chlorophyll $a$, phaeopigments). Each core was cut into $1 \mathrm{~cm}$ slices and frozen (samples for photosynthetic pigment analysis in $-80^{\circ} \mathrm{C}$; other samples in $-20^{\circ} \mathrm{C}$ ). In both seasons temperature and salinity were measured in the water column at each station (in July with use of CT-Set mounted at Hydro Bios MultiNet, in January with use of a Sea-Bird SBE 911 plus CTD system).

\section{Laboratory treatment}

Chlorophyll $a(\mathrm{Chl} a)$ and phaeopigment concentrations in the sediment samples were measured using a fluorometric method. Pigments were extracted from freeze-dried sediments in $90 \%$ acetone for $24 \mathrm{~h}$ at $4{ }^{\circ} \mathrm{C}$ (Evans et al. 1987). Measurements were performed with use of a Perkin Elmer LS55 Fluorescence Spectrometer. Emissions at $671 \mathrm{~nm}$ and excitations at $431 \mathrm{~nm}$ were measured before and after sample acidification with $1 \mathrm{M} \mathrm{HCl}$, and used to calculate the chlorophyll $a$ and phaeopigment concentrations, according to the method described by Evans and O' Reilly (1983). The sum of chlorophyll $a$ and phaeopigment concentrations is defined as chloroplastic pigment equivalent (CPE). Grain size distribution was determined with a Malvern Mastersizer 2000 particle size analyser. Grain size parameters were recalculated using the GradiStat 4.0. software. The POC content (\%) was determined via continuous flow-elemental analysis-isotope ratio mass spectrometry (CF-EA-IRMS) at the University of Liège with use of a Vario Micro Cube elemental analyzer (Elementar Analysensysteme $\mathrm{GmBH}$, Hanau, Germany). Prior to analysis, sediments were dried at $60{ }^{\circ} \mathrm{C}$ for $48 \mathrm{~h}$, ground, and acidified with direct addition of $1 \mathrm{M}$ 
$\mathrm{HCl}$ to remove carbonates (Hedges and Stern 1984). Then the acid was diluted with distilled water, samples were centrifuged, and, after the removal of the solution, dried again at $60{ }^{\circ} \mathrm{C}$ for $24 \mathrm{~h}$. Subsamples of about $15 \mathrm{mg}$ of the sediment were packed into tin capsules and subsequently analyzed on the mass spectrometer for the POC content and $\delta^{13} \mathrm{C}$.

All specimens from macrofauna samples were enumerated and identified to the lowest possible taxonomic level. Specimens were photographed with a Leica DFC450 digital camera connected to Leica M205C stereomicroscope. Taxon-specific measurements (Online Resources 1 Table ESM2) were performed with use of Leica LAS Manual Measurements software. In the case of species occurring in numbers higher than 250 per sample, a subsample of 200 randomly picked specimens was measured and these data were extrapolated to the total number of individuals in a sample. The size determination methods for macrofauna and meiofauna are provided in the next section.

The meiofauna samples were centrifuged three times in a solution of colloidal silica (Ludox TM-50, density of $1.18 \mathrm{~g} \mathrm{~cm}^{-3}$ ) and stained in a $4 \%$ buffered formaldehyde solution with Rose Bengal for at least $24 \mathrm{~h}$ (Heip et al. 1985). Then samples were sieved and only specimens that passed through $500 \mu \mathrm{m}$ mesh and retained on $32 \mu \mathrm{m}$ mesh were analyzed. All specimens were identified to the higher taxa (mostly phylum) level. Five hundred randomly selected individuals of Nematoda (the dominant taxon) and all individuals of other taxa were photographed with Leica DFC450 digital camera connected to Leica M205C stereomicroscope. Nematode lengths and average widths were measured using semi-automated method of image analyses (Mazurkiewicz et al. 2016); in other taxa lengths and maximum widths were measured manually.

In total from 1466 to 2130 organisms (meiofauna and macrofauna) were measured at each station (Online Resources 1 Table ESM1).

\section{Statistical analysis}

Differences in environmental parameters (POC, Chl $a, \mathrm{CPE}$ ) in surface sediments $(0-2 \mathrm{~cm})$ between two seasons (Season) and among three stations (Station) were tested with use of two-way balanced analysis of variance (ANOVA). Pairwise post hoc comparisons were performed with use of a Tukey's adjustments of $p$-values. Prior to analysis data were transformed using power (Box-Cox) transformation to normalize the data and equalize the variance.

The biovolumes of meiofaunal and macrofaunal individuals were calculated based on the measured dimensions. For meiofauna, biovolume was calculated with use of the Feller and Warwick (1988) formula: $V=L \times W^{2} \times c$ where $V$ is the volume, $L$-the maximum length, $W$-the maximum width, and $c$-taxon-specific coefficient. Dry mass (DM) was estimated using following the equations: wet mass $(\mathrm{WM})=1.13 \times V, M=0.25 \times \mathrm{WM}($ Feller and Warwick 1988). For macrofauna-body shapes were matched with geometric figures (Hillebrand et al. 1999; Online Resources 1 Table ESM2). The total lengths of fragmented polychaetes (needed for the individual biovolume estimation) were calculated with use of regression formulas based on relationships between widths of selected chaetigers and animal lengths (Górska et al. 2019). WM was calculated by multiplying the biovolume by a specific gravity factor of 1.13 (Andrassy 1956). For Crustacea and Ophiuroidea, WM was obtained from measured dimensions using published conversion factors (Berestovsky et al. 1989). Body mass conversion factors (Brey et al. 2010) were used for obtaining the shell free WM (in case of calcifying organisms) and subsequently DM.

Differences in average individual size (indicated by individual DM) between two seasons (Season) and among three stations (Station) were tested for meiofaunal and macrofaunal taxa represented by more than 30 specimens in every sample. Data were transformed using power (Box-Cox) transformation. Two-way unbalanced analysis of variance (ANOVA type II) was performed to examine the differences according to stations and season. Pairwise post hoc comparisons were performed with a Tukey's adjustments of $P$ values.

Abundance and biomass size spectra were calculated by using groupings of organisms based on their individual DM $(\mu \mathrm{g})$ on a $\log _{2}$ scale Each specimen was assigned to a body size class and the total abundance (individuals $0.1 \mathrm{~m}^{-2}$ ) and biomass ( $\mu \mathrm{g} \mathrm{DM} 0.1 \mathrm{~m}^{-2}$ ) of all specimens in each class were calculated and used to construct abundance and biomass size spectra, respectively (Sheldon et al. 1972; Duplisea and Drgas 1999). Each size class is two times larger than the preceding one. For example, size class five includes organisms of DM that is $\geq 2^{5}$ and $<2^{6} \mu$ g (i.e., $\geq 32$ and $<64 \mu \mathrm{g}$ the size class covers a range of $32 \mu \mathrm{g}$ ), while size class four includes dry mass values that are $\geq 2^{4}$ and $<2^{5} \mu$ g (i.e., $\geq 16$ and $<32 \mu \mathrm{g}$ - the size class covers a range of $16 \mu \mathrm{g}$ ).

Multivariate analyses were applied to explore the patterns of similarity in taxonomic composition (abundance or biomass per taxon) and taxonomic coupled with size class composition (abundance or biomass per size class/taxon at three stations and in two seasons. Bray-Curtis similarities were calculated for abundance (square-root transformed) and DM (fourth-root transformed) in samples for: (1) meiofauna higher taxa, (2) meiofauna higher taxa/size classes, (3) macrofauna taxa, and (4) macrofauna taxa/size classes. Two different data transformations were used due to different magnitudes of variability in biomass and abundance data. The effect of season on these compositions was tested using one-way PERMANOVA model with permutation of 
residuals under a reduced model, with Monte Carlo sampling used to increase the interpretability of the test due to low number of possible permutations (Anderson et al. 2008).

The normalized biomass size spectra (NBSS, Platt and Denman 1977, 1978) were plotted to correct for the distortion of biomass distribution caused by the logarithmic increase in width of size class bins in biomass or abundance size spectra (Sprules and Barth 2016). The total biomass in every size class was normalized by dividing it by the range of this size class ( $\Delta$ size class) and $\log _{2}$ transformed. We determined the parameters of NBSS in every sample using ordinary least squares (OLS) linear regression of normalized biomass (NB) versus SizeClass.

To assess the influence of Station and Season on the intercepts and slopes of NBSS, the multiple linear regression was carried out with SizeClass as a continuous covariate and Station and Season and as categorical predictors. A stepwise procedure was applied to find the most parsimonious regression model on the basis of Akaike's information criterion (AIC, Akaike 1974). The analysis of covariance (ANCOVA) was performed on the most parsimonious model to confirm the significance of predictors of this model. Tukey-adjusted post hoc comparisons were performed to assess significant differences between coefficients of the most parsimonious regression model.

The calculation of Bray-Curtis similarities and PERMANOVA analysis were performed in PRIMER with PERMANOVA + software (version 7; Clarke and Gorley 2015). The other statistical analyses were performed in R statistical environment (R Core Team 2018, Online Resources 1 Table ESM3).

\section{Results}

\section{Seasonal changes in abiotic parameters}

In summer, salinity was homogenous throughout the water column, except for the uppermost $20 \mathrm{~m}$ where it was distinctly lower (possibly due to meltwater discharge), while the temperature was slightly higher in the few upper meters and then decreased with depth to the bottom layers. In winter both salinity and temperature were consistent throughout the water column (Fig. 2). Near-bottom temperatures and salinities were higher in summer (on average $2.37^{\circ} \mathrm{C}$ and $35.34{ }^{\circ} \mathrm{C}$, respectively) than in winter $\left(1.23{ }^{\circ} \mathrm{C}\right.$ and $34.84{ }^{\circ} \mathrm{C}$, Fig. 2).

Sediments at sampling stations consisted mostly of clays and silts, which summed (mud) constituted from 60 and $100 \%$ of sample content (Fig. 2). The POC content in sediments decreased slightly with sediment depth, the values differed among the three stations (ANOVA, $\left.F_{2,10}=185.2, p<0.0001\right)$, but not between the two seasons (ANOVA, $F_{1,10}=0.1, p=0.7090$ ). The highest values in the surface layer $(0-1$ and $1-2 \mathrm{~cm})$ were noted at station KB1 $(2.18 \pm 0.18 \%, n=4)$, lower at station KB2 $(1.76 \pm 0.12 \%, n=4)$, and the lowest at KB3 $(1.09 \pm 0.05 \%$, $n=4)$; values at each station were significantly different from two others (Tukey-adjusted post hoc comparisons, $p<0.0001)$. Regarding the photosynthetic pigments, their concentrations decreased with sediment depth (Fig. 2). There was no seasonal difference in Chl $a$ content in surface sediments (0-1 and 1-2 cm; ANOVA, $F_{1,30}=3.2$, $p=0.0845)$, however there were significant differences among stations (ANOVA, $F_{2,30}=9.6, p=0.0006$ ). At station KB1 average Chl $a$ content in surface sediment was significantly higher $(7.79 \pm 4.38[n=12]$, Tukey-adjusted post hoc comparisons $p<0.05)$ comparing to KB2 and KB3 stations $(3.65 \pm 1.58[n=12]$ and $2.93 \pm 1.35[n=12]$, respectively). The average CPE contents in upper sediment layers $(0-2 \mathrm{~cm})$ were on average almost two times higher in summer than in winter $(40.98 \pm 17.38[n=18]$ vs. $22.12 \pm 13.86 \mu \mathrm{g} \mathrm{g}^{-1}[n=18]$; ANOVA $F_{1,30}=16.6$, $p=0.0004)$. CPE concentration also varied among stations (ANOVA, $F_{2,30}=5.2, p=0.0120$ ). The highest mean concentration of CPE in surface layer $(0-1$ and $1-2 \mathrm{~cm})$ was noted at station $\mathrm{KB} 1: 41.66 \pm 17.60 \mu \mathrm{g} \mathrm{g}^{-1}$ $(n=12)$; however, it differed significantly only from KB3 $\left(23.09 \pm 12.72 \mu \mathrm{g} \mathrm{g}^{-1}[n=12]\right.$; Tukey-adjusted post hoc comparisons $p<0.05)$. Average CPE concentration in surface sediments at KB2 was $29.90 \pm 19.76 \mu \mathrm{g} \mathrm{g}^{-1}(n=12)$.

\section{Seasonal changes in taxonomic composition, abundance, and biomass of meio- and macrofauna}

Meiofauna was composed of 13 taxa (Online Resources 1 Table ESM4). The total density ranged from $135 \times 10^{3}$ to $389 \times 10^{3}$ ind. $0.1 \mathrm{~m}^{-2}$ in summer and from $131 \times 10^{3}$ to $326 \times 10^{3}$ ind. $0.1 \mathrm{~m}^{-2}$ in winter (Online Resources 1 Table ESM3). The biomass ranged from 32 to $62 \mathrm{mg} \mathrm{DM}$ $0.1 \mathrm{~m}^{-2}$ in summer and from 19 to $147 \mathrm{mg}$ DM $0.1 \mathrm{~m}^{-2}$ in winter. Meiofauna was dominated by nematodes, both in terms of abundance (94-97\%) and biomass (73-92\%). Macrofauna was represented by 132 species (Online Resources 1 Table ESM5). The total density varied from 776 to 1410 ind. $0.1 \mathrm{~m}^{-2}$ in summer and from 940 to 1563 ind. $0.1 \mathrm{~m}^{-2}$ in winter, and the ratios of winter/summer densities at stations varied from 1.10 to 1.52 . The biomass varied in summer from 1211 to $1959 \mathrm{mg}$ DM $0.1 \mathrm{~m}^{-2}$, and in winter from 1726 to $3879 \mathrm{mg} \mathrm{DM} 0.1 \mathrm{~m}^{-2}$; winter/ summer ratios ranging from 1.42 to 2.31 . The taxonomic composition of both meiofauna and macrofauna expressed in taxa or taxa/size class abundance or biomass did not differ between the seasons (PERMANOVA, $p>0.5$ ). 


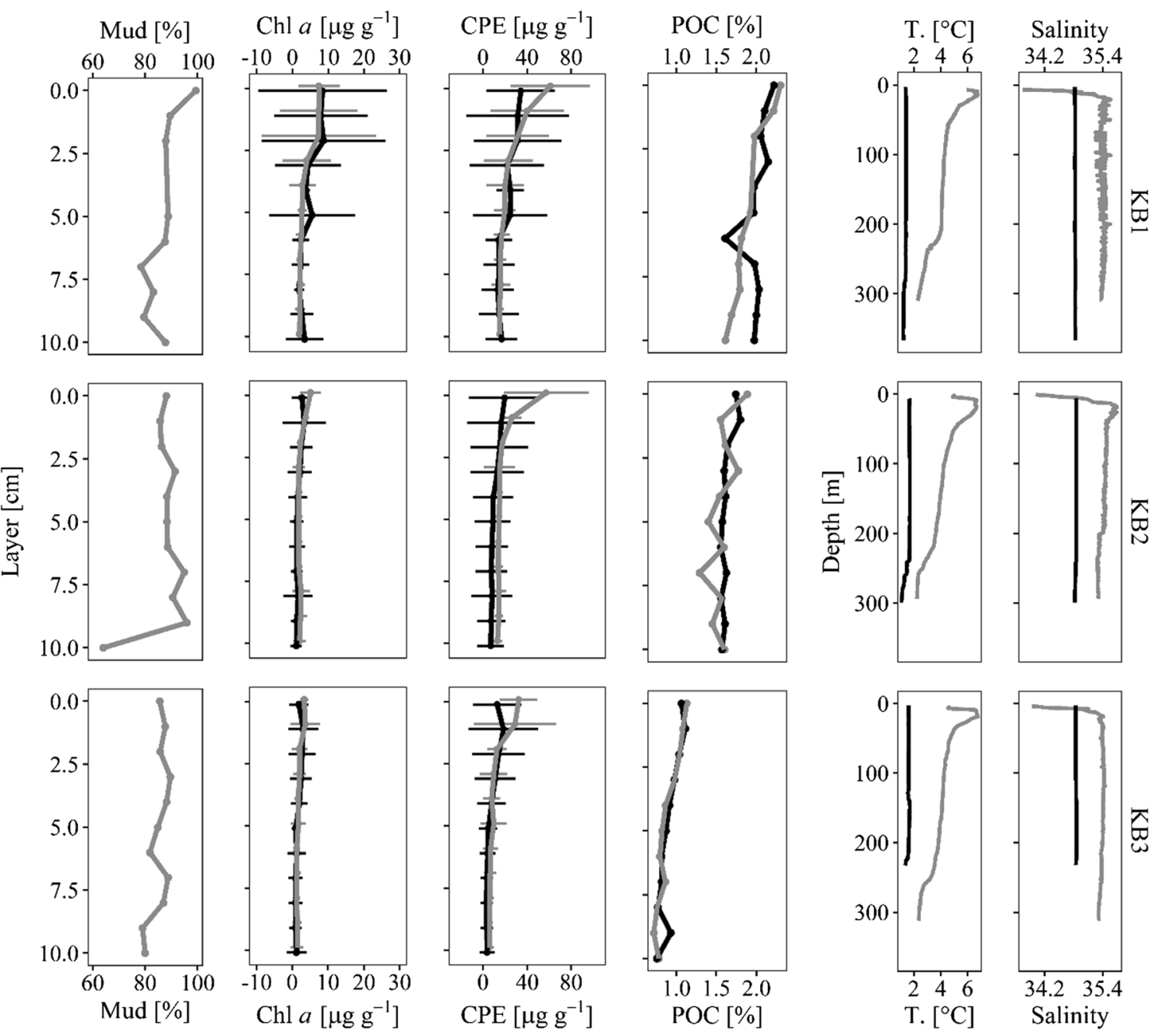

Fig. 2 Environmental variables at stations and in seasons. The plots present mud content, chlorophyll a content ( $\mathrm{Chl}$ a, mean for three replicates and $0.95 \mathrm{CI}$ ), CPE (chloroplastic pigment equivalent) content

\section{Seasonal variability of benthic size structure}

Four macrofaunal taxa (polychaetes: Galathowenia oculata, Lumbrineris spp., Maldane sarsi, and Prionospio cirrifera) and meiofaunal nematodes occurred with more than 30 specimens in every sample. The individual biomass differed between seasons and between seasons within each station for all dominant taxa (ANOVA, $p<0.05$, Table 1). For G. oculata, seasonal differences occurred at stations KB1 and KB3 where specimens had higher biomasses in summer (median $=339$ vs. 83 and 236 vs. $93 \mu \mathrm{g}$ DM, respectively; Fig. 3). Specimens of Lumbrineris spp. collected in winter had higher biomasses than those sampled in summer (median $=604$ vs. $354 \mu \mathrm{g} \mathrm{DM}$ ) only at KB3 station. For $M$. sarsi, seasonal differences were noted at stations KB2 and KB3 where specimens had higher biomasses in summer (median $=260$ vs. 413 , and 276 vs. $228 \mu \mathrm{g} \mathrm{DM}$, stations (mean for three replicates and $0.95 \mathrm{CI}$ ) and POC (particulate organic matter) in $10 \mathrm{~cm}$ of sediment cores and water column temperature (T.) and salinity. Black lines-winter, gray lines-summer

respectively). Specimens of Prionospio cirrifera had lower winter biomass at stations KB1 (median $=797$ vs. $514 \mu \mathrm{g}$ $\mathrm{DM})$ and KB2 (median $=1244$ vs. $791 \mu \mathrm{g} \mathrm{DM})$, while at $\mathrm{KB} 3$ in winter they had higher biomass (median $=1451$ vs. $3700 \mu \mathrm{g}$ DM). For Nematoda the significant seasonal differences occurred at all stations: summer biomasses were higher at KB1 (median $=0.079$ vs. $0.058 \mu \mathrm{g} \mathrm{DM})$ and KB2 (median $=0.045$ vs. $0.038 \mu \mathrm{g}$ DM) while at KB3 specimens had higher biomasses in winter (median $=0.028$ vs. $0.068 \mu \mathrm{g}$ DM).

Both abundance and biomass size spectra had similar trimodal shapes in summer and winter at KB1 and KB2; the shapes were bimodal at station KB3. Size classes ranged between -9 and 20 (Fig. 4). In abundance size spectra, the peaks were observed between size classes -6 to $-4,6$ to 9 , and 12 to 14 . The troughs were observed in size classes 4 and 11 to 12 . In biomass size spectra, the 
peaks were observed at size classes 0 to 2,9 to 11 , and at highest size classes (16 to 20). The troughs in biomass size spectra were present in the same size classes as in the abundance size spectra.

There were some differences in biomass size spectra shapes among stations (Fig. 4). The first peak at KB2 was flatter and wider (from -5 to 3 ) compared to KB1 and KB3 where it was steeper and narrower (from -2 to 2). Only at KB2 organisms noted in size classes 18 and 20 were noted.

The shapes of abundance and biomass size spectra in the two seasons were consistent at each station. Still, there were some slight differences in peak location (Fig. 4). At all stations in summer the abundance and biomass in the first trough (size class 4) were lower than in winter. At KB2, first biomass peak was less pronounced in winter ( -1 to 0 ) than in summer ( 0 to 1 ); size classes 18 and 20 were present only in winter. Moreover, in summer the maximum biomass occurred in size class 16 while in winter it was found in size class 20. At station KB3, the positions of both biomass and abundance peaks were shifted by -1 towards lower size classes in summer compared to winter. Regarding the biomass, both peaks were higher in winter than in summer.

Meiofauna covered 13 size classes (from -9 to 3 ). Nematoda made up 71-100\% of biomass in size classes from - 9 to 2 (Fig. 5). The macrofaunal organisms were spread across 24 size classes (from -3 to 20). Biomass in size classes from 2 to 20 was dominated by Annelida (66 to 100\%). Mollusca had a considerable contributions (11-30\%) to biomass in size classes 13,14, and 16, and Arthropoda (Crustacea) contributed significantly in size classes 2,14 , and 15 (16-17\%, Fig. 6). The shift in dominance from nematodesmeiofaunal dominant taxon-to polychaetes-macrofaunal dominant taxon-was observed between size classes 1 and 3 (Fig. 5).

A significant linear relationship between $\mathrm{NB}$ and SizeClass was found for all the samples $(p<0.0001$, Table 2). The intercepts and slopes of NBSS varied between $10.72 \pm 0.47$ to $12.00 \pm 0.45$ and $-0.50 \pm 0.07$ to $-0.58 \pm 0.05$, respectively.

The most parsimonious multiple regression model describing NBSS incorporated two covariates: SizeClass and Station, without interactions (Eq. 1):

$\mathrm{NB}_{i}=\beta_{1}+\beta_{2} \times$ SizeClass $_{i}+\beta_{3} \times$ Station $_{i}+\varepsilon_{i}$

where $\beta_{1}$ is the intercept, $\beta_{2}$ is the slope $\beta_{3}$ is the effect of Station on the intercept, and $\varepsilon_{\mathrm{i}}$ is the error term. The significance of these covariates was also confirmed by ANCOVA $(p<0.05)$. The intercept in the multiple regression (Eq. 1) was significantly different (Tukey-adjusted post hoc comparisons $p<0.05$ ) only between KB2 and KB3 stations $(10.77 \pm 0.41$ vs. $11.89 \pm 0.31$, respectively) with a common slope $=-0.54 \pm 0.02 \times$ SizeClass (Fig. 6). 
Fig. 3 Individual dry mass (DM) of the most common macrofaunal species (top four panels) and meiofaunal nematodes (bottom panel) at the three stations by season. Boxmedian with $0.25-0.75$ percentile; dots—single specimen observations,$\neq$ - statistically significant differences between seasons within each station (post hoc pairwise comparison with Tukey's adjustment of $p$-values $p<0.05$ )
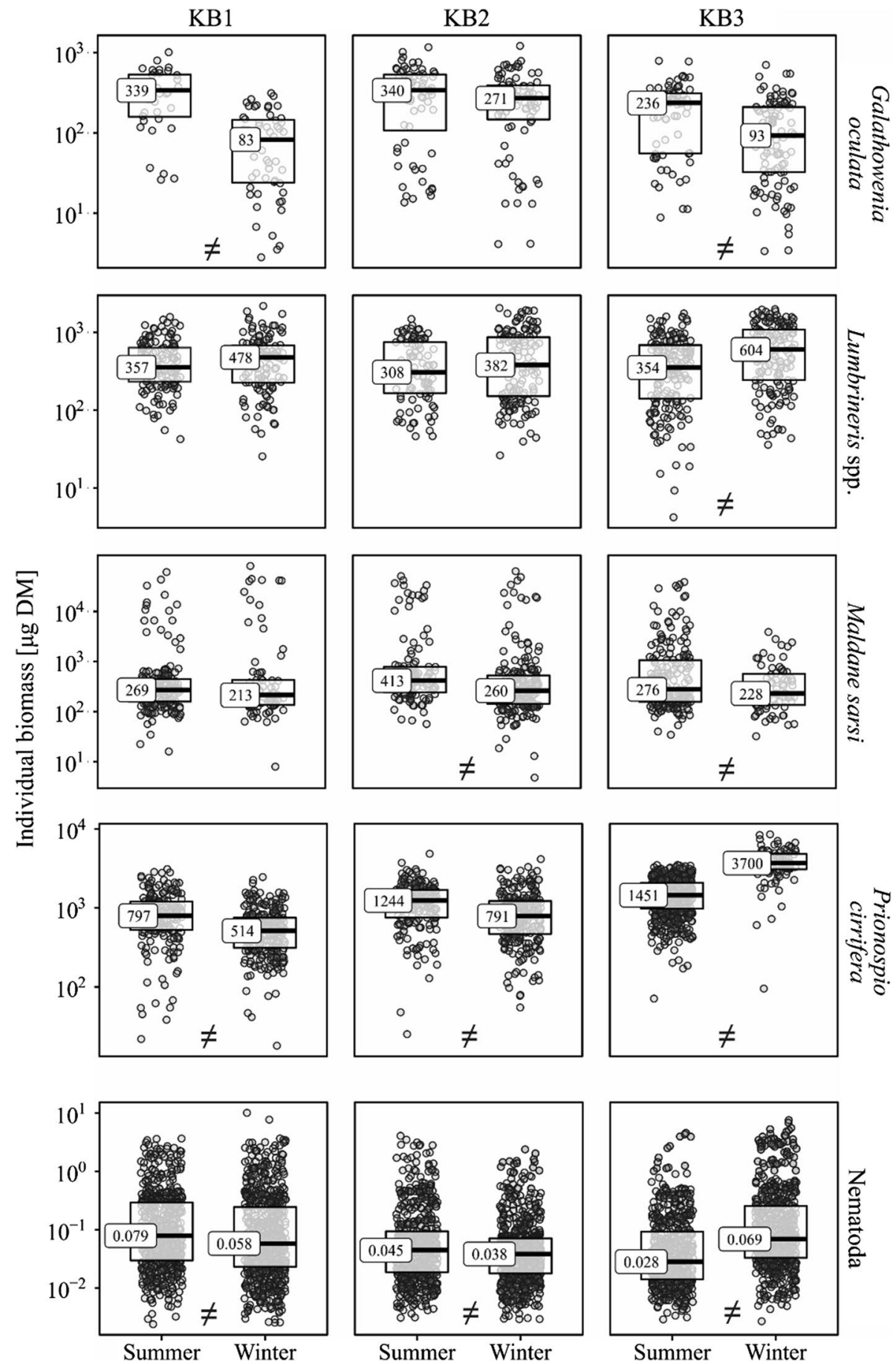

\section{Discussion}

\section{Benthic response to seasonal variability in Kongsfjorden ecosystem}

Despite the strong seasonality in pelagic processes and organic matter supply to the sea bottom in Kongsfjorden (Lalande et al. 2016), the abundance and biomass size spectra showed little variability between the two studied seasons. Quiroga et al. (2016) stated that benthic biomass size spectra may be useful as indicators of short-term local dynamics of environmental factors since slopes, and intercepts of estuarine NBSS varied in response to seasonal variability in organic and mineral matter supply to the sea bottom. Effects of high summer supply of inorganic matter (decrease in meiofauna and macrofauna abundancies) were also detected by (Pawłowska et al. 2011) in Adventfjorden near Adventelva and Longyearelva rivers mouth. 

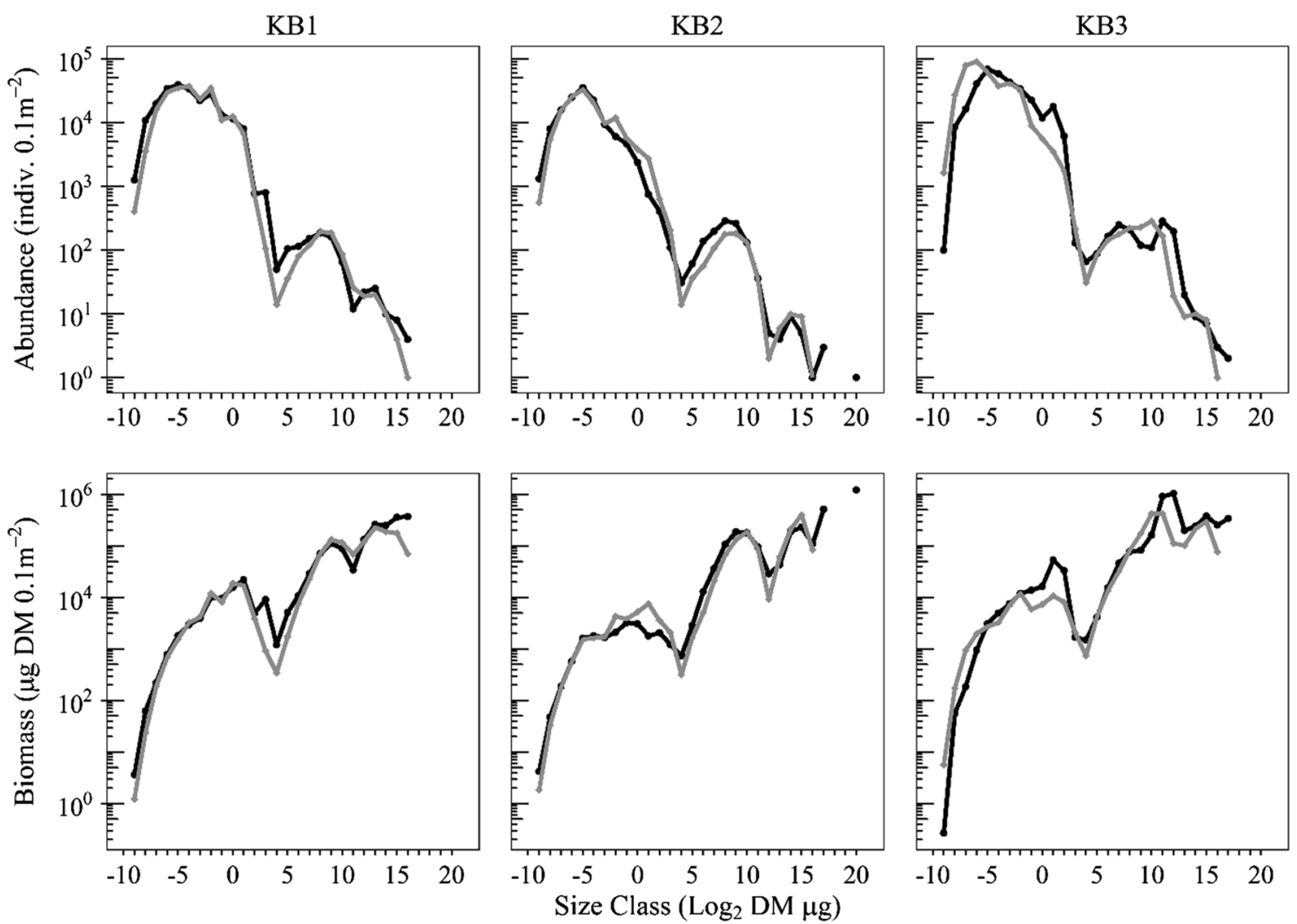

Fig. 4 Abundance size spectra (top row) and biomass size spectra (bottom row) at investigated stations in summer (gray lines) and winter (black lines)

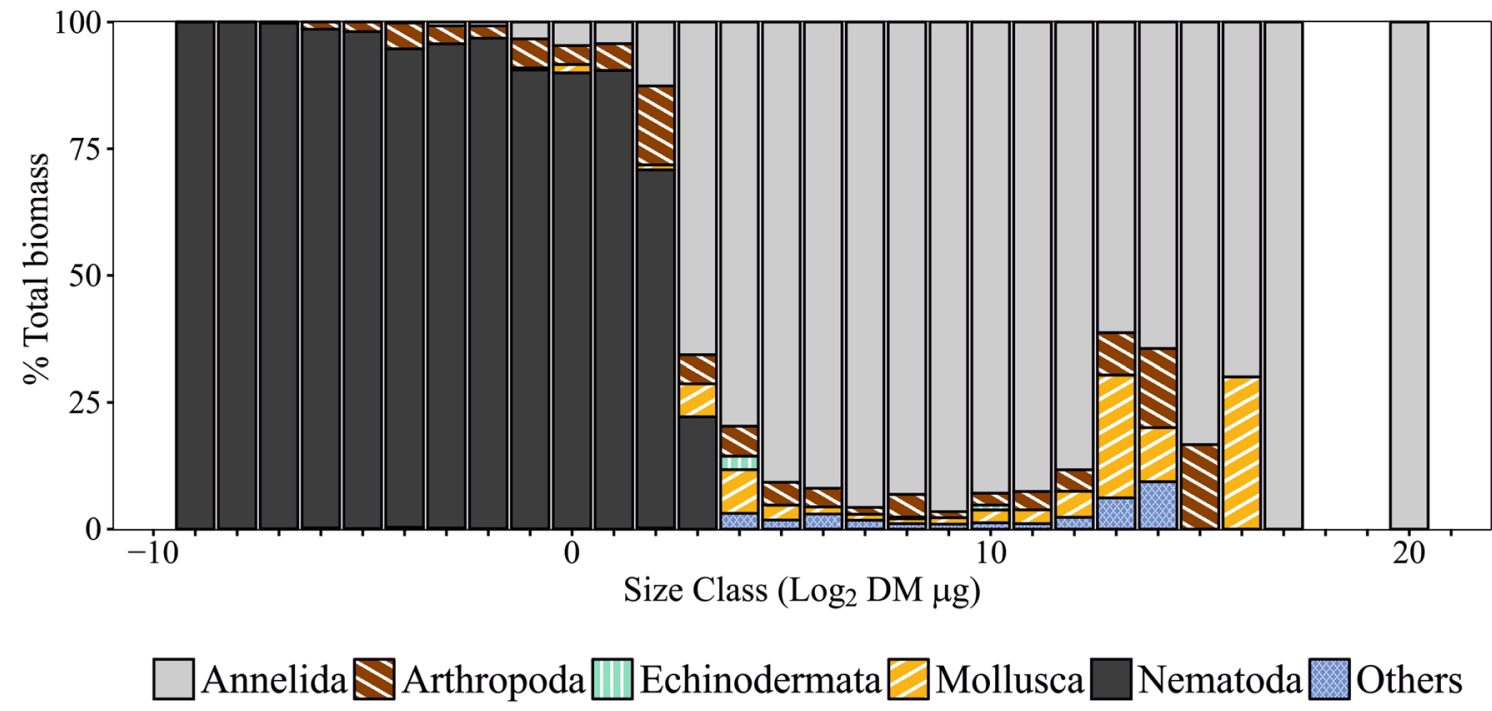

Fig. 5 Contributions of major phyla to total biomass in size classes - average based on data from all stations and seasons

However, stations in present study were located in the central and outer parts of Kongsfjorden, where sediments are stable and sedimentation of glacial sediments is low (Włodarska-Kowalczuk et al. 2005) and this may be one of the reasons why we did not observe seasonal changes in benthic communities.

In Kongsfjorden the seasonal cycle of primary production is strongly pronounced with a marked peak in spring 
Fig. 6 NBSS with fitted regression lines for the most parsimonious model-Eq. 1 (the intercepts are significantly different between KB2 and KB3 (Tukey-adjusted post hoc comparisons $p<0.05)$ ). Summerdots, winter-triangles
Table 2 OLS linear regression parameters of the normalized biomass size spectra calculated for individual samples

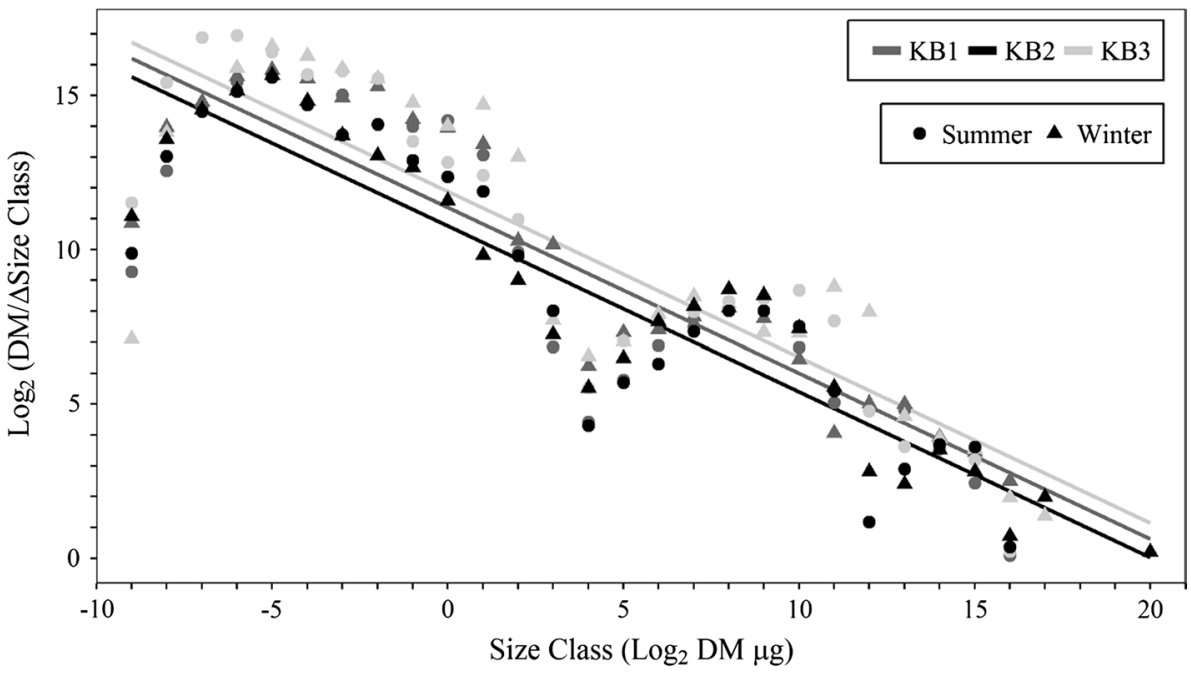

\begin{tabular}{llllll}
\hline Station & Season & Intercept $\left(\beta_{1}\right) \pm \mathrm{SE}$ & Slope $\left(\beta_{2}\right) \pm \mathrm{SE}$ & Adj. $R^{2}$ & $p$ \\
\hline KB1 & Summer & $11.12 \pm 0.54$ & $-0.54 \pm 0.07$ & 0.73 & $<0.0001$ \\
& Winter & $11.65 \pm 0.41$ & $-0.54 \pm 0.05$ & 0.82 & $<0.0001$ \\
KB2 & Summer & $10.72 \pm 0.47$ & $-0.54 \pm 0.06$ & 0.78 & $<0.0001$ \\
& Winter & $10.79 \pm 0.38$ & $-0.53 \pm 0.04$ & 0.86 & $<0.0001$ \\
KB3 & Summer & $12.00 \pm 0.45$ & $-0.58 \pm 0.05$ & 0.82 & $<0.0001$ \\
& Winter & $11.81 \pm 0.59$ & $-0.50 \pm 0.07$ & 0.67 & $<0.0001$ \\
\hline
\end{tabular}

The normalized biomass (NB) was modeled as a function of size class: $\mathrm{NB}_{i}=\beta_{1}+\beta_{2} \times$ SizeClass $_{i}+\varepsilon_{i}$, where $\beta_{1}$ is the intercept, $\beta_{2}$ is the slope and $\varepsilon_{\mathrm{i}}$ is the error term

(Svendsen et al. 2002; Hop et al. 2006). The sedimentation of fresh pelagic organic matter in late spring/early summer has been linked to increased values of CPE in sediments (a proxy for the fresh/labile organic matter, García et al. 2010). However, in the present study, no difference between winter and summer was noted for either the POC or Chl $a$ content in sediments. This agrees with studies from the Beaufort Sea where also lack of seasonal differences in Chl $a$ and POC content in sediments was observed (Renaud et al. 2007). On the other hand seasonal variation in POC in sediments was found in Adventfjorden (Svalbard) station located in shallow zone (at $40 \mathrm{~m}$ depth) influenced by the nearby river outlet (Zajączkowski et al. 2010; Pawłowska et al. 2011). The higher CPE resulting from increased phaeophytin, products of Chl $a$ degradation, may indicate that in the late summer the organic matter produced in the water column reaches the bottom after being grazed by mesozoplankton (Chen et al. 2016). However, according to Krajewska et al. (2017) sum of Chl $a$ and its derivatives (CPE) is a much better indicator of pelagic primary production than only $\mathrm{Chl} a$ content. Chl $a$ is decomposed very fast due to oxygenation and zooplankton grazing that in surface water layers may result in consumption of even up to $97 \%$ of the daily $\mathrm{Chl} a$ production (Verity et al. 2002). The POC content indicates that the total pool of organic matter can remain stable throughout the year, even if the pelagic production ceases in autumn. An alternative source of organic matter is kelp detritus, which is delivered to sediments mainly in autumn when kelp blades are being physically destroyed (Shunatova et al. 2018). The lack of seasonal variability in POC content in Kongsfjorden sediments (contrasting with clear difference in vertical fluxes recorded by Lalande et al. 2016) was documented by Bourgeois et al. (2016) and explained by relatively stable production of zooplankton fecal pellets over the year.

However, it must be noted that in Arctic there are regions that differ in the strength of seasonal processes. For example, in shallower regions of much higher spring productivity where degradation of organic matter in water column may be less efficient than in fjords such as polynyas, clear seasonal differences in Chl $a$ were detected (Cooper et al. 2002). Consequently, the benthic response to seasonality in phytodetritus inputs may vary across habitats and regions. For example, food-limited deep-sea communities may be more dependent on the strong ice-edge-related fluxes of phytodetritus (Schewe and Soltwedel 2003) and these seasonal high inputs of phytodetrital matter may shape the seasonal variability in standing stock and diversity of biota. Also in high Arctic fjords, where ice-cover and shorter vegetation period 
implies lower pelagic productivity, benthos can express seasonal variability as suggested by Morata et al. (2013) for northern Svalbard fjord, Rijpfjorden. It is possible that in those regions detectable seasonal variation in size structure of benthic communities can also occur, but further studies are needed to test it.

Lack of seasonal patterns in benthic size spectra is consistent with the study of Włodarska-Kowalczuk et al. (2016), who did not found a clear response of Kongsfjorden benthic standing stocks or diversity to changes of organic matter supply during four seasons. Their findings and the present study support the hypothesis of the sediment 'food bank' existence in the polar sediments that was first formulated for the West Antarctic Peninsula by Mincks et al. (2005). According to this hypothesis large amounts of organic carbon produced during the spring blooms and deposited on the bottom may persist in the sediments for a long period of time due to low rates of bacterial mineralization in low temperatures and can maintain benthic communities at constant levels on a year-round basis (Mincks et al. 2005; Glover et al. 2008). It is evident that Kongsfjorden's benthic fauna is not food-limited and is not dependent on the seasonal pulses of pelagic primary productivity. Moreover, Renaud et al. (2015) reported that in the Spitsbergen fjords macroalgal detritus can contribute up to $69 \%$ to macrobenthic consumers' diet. The reliance on a food source that is supplied from the shallow rocky banks to the deeper basins year-round can release benthic communities from seasonal control. Also the patterns observed in Kongfsjorden which is a productive/advective system with high local pelagic (Hodal et al. 2012) and benthic (Woelfel et al. 2010) primary productivity, and strong advection of Atlantic waters that transport organisms and organic matter from shelf, may differ from the situation in some other Arctic fjords. For example, Morata et al. (2013) reported that in Rijpfjorden, an area with a much shorter primary production period, the macrobenthic biomass was lower in winter than in summer and that the benthic communities in January responded with increased activity to experimental addition of fresh organic matter.

\section{Benthic size spectra of an Arctic fjord}

The functioning of a system (e.g., productivity, rate of the energy flow through trophic levels) may be reflected in the size spectra characteristics. The intercept of NBSS can be an indicator of total biomass in the community (Sprules and Munawar 1986; Quiroga et al. 2012) or a rate of primary production in the system in case of pelagic systems (Zhou 2006). However, it must be noted that comparisons of intercept (treated as a proxy of total biomass) are only possible when spectra represent similar size class range (Hua et al. 2013). The intercepts of NBSS plotted for Kongsfjorden fauna were higher than those reported by most other studies
(Saiz-Salinas and Ramos 1999; Quiroga et al. 2005, 2012, 2016), but similar to those of the communities inhabiting highly productive regions and sediments with high organic matter content (Akoumianaki et al. 2006; Hua et al. 2013). But it must be noted that these differences in intercepts may result from various sampling gears used and not overlapping size classes with our studies.

The NBSS slope is regarded as an indicator of energy utilization within community as it tends do decrease with growing trophy of the system i.e., from oligotrophy to eutrophy (Sprules and Munawar 1986). Lower slopes indicate higher efficiency of biomass transfer to larger sized organisms, and higher accumulation of biomass in these organisms (Sprules and Munawar 1986; Gaedke 1992). If an ecosystem is in a theoretically steady state like pelagic systems of Sargasso Sea or central gyre in the North Pacific Ocean (Platt and Denman 1978; Rodriguez and Mullin 1986), with lack of disturbance and stable flux of energy from smaller to larger organisms, the slope coefficient should be close to -1 . Deviations from the steady state may be detected by values of slope coefficient different than -1 (Sprules and Munawar 1986).

On the other hand, in detritivorous benthic communities that are subsidized with additional food sources, size spectra slopes may be less negative comparing to steadystate pelagic communities, because larger bodied are not food-limited (Trebilco et al. 2013). Therefore, it is assumed that a slope of benthic NBSS $>-1$ reflects highly productive system (Drgas et al. 1998; Saiz-Salinas and Ramos 1999). Slopes found in the present study $(\sim-0.5)$ are similar to those found by Akoumianaki et al. (2006) at stations enriched in organic matter near the Spercheios River mouth (Maliakos Gulf, Greece), suggesting substantial food resources for benthic organisms in Kongsfjorden. Moreover, the slope coefficient reported in this study also suggests lack of disturbances. Disturbances, e.g., extensive fishing (Graham et al. 2005), eutrophication (Quiroga et al. 2012), or low oxygen levels (Quiroga et al. 2005), cause elimination of large organisms and promotion of small size classes (and the size spectra slope steepening).

The shapes of the observed benthic size spectra were similar to those reported in other studies. Usually, they are bimodal with a well pronounced trough between the modes, corresponding to two major benthic groups: meiofauna and macrofauna (Schwinghamer 1981; Warwick and Clarke 1984; Duplisea and Drgas 1999; Kelly-Gerreyn et al. 2014). Some studies, however, reported also trimodal spectra, with two peaks within the macrofauna size range (Hua et al. 2013; Górska and Włodarska-Kowalczuk 2017), similar to spectra observed in this study at stations KB1 and KB2. Still, obvious trough (region of low biomass) separating meiofauna and macrofauna was observed in every sample. This trough is regarded as a characteristic property of benthic 
size structure (Warwick and Clarke 1984), and is not related to different sampling procedures for meio- and macrofauna (Schwinghamer 1981; Duplisea and Drgas 1999; Warwick 2014). It is assumed that the shift from interstitial meiofauna to burrowing and sedentary macroscopic surface dwellers occurs within the range of size classes corresponding to the trough (Schwinghamer 1981). This is confirmed by the shift in major phyla contributions to size classes observed in the present study, where above size class 3 the dominant meiofauna component (Nematoda) is replaced by major macrofaunal component (Polychaeta). The size class ranges of meiofana and macrofauna overlapped between -3 and 3 size classes, but the very high dominance ( $>80 \%$ of biomass) of Nematoda until two size class confirms good adaptation of meiofauna to dwelling in the interstitial habitat (Warwick 2014).

\section{Seasonal patterns in size structure of dominant taxa}

In our study, differences in size of dominating species varied in magnitude and direction of change among stations and species. The decrease of individual biomass in winter was reported for Galathowenia oculata and Maldane sarsi, while the opposite trend was observed for Lumbrineris spp. The first two species are sedentary tube building deposit feeders, while the later one is a mobile carnivorous worm, thus the seasonal variability in the size structure of the populations of these species may induce subtle differences in benthic detritus pool processing or bioturbation. However, the consistent composition of the community in terms of distribution of the individuals among the size classes implies that the basic functioning aspects at the community level as productivity or total carbon mineralization will remain little changed. Observations of significant seasonal changes for individual species that are not translated into the whole community level were reported also for other systems. Datta and Blanchard (2016) modeled the seasonal variability in size spectra in fish populations and communities in the North Sea and described significant seasonal changes for individual species, but none at the whole community level. For meiofaunal nematodes and Prionospio cirrifera, the individual biomass was lower at stations KB1 and KB2, but higher at KB3. Włodarska-Kowalczuk et al. (2016) showed no difference in mean individual biomass of Nematoda between winter and summer in the outer basin of Kongsfjorden, but higher individual biomass in spring. This was explained by the effect of the seasonal recruitment following the spring bloom. High values of polychaete summer biomass could also be explained by their reproduction strategies (Gooday 2002). According to Kukliński et al. (2013), who studied seasonal patterns of meroplankton in Adventfjorden, pulse of planktotrophic larvae occurs from spring to early summer. While the settlement can be prolonged even until early winter, it is the most intense soon after the peak bloom period. In Adventfjorden the polychaete larval peak was reported to occur from May to late June, and the timing was strongly correlated with the Chl $a$ concentrations in the water column (Stübner et al. 2016). This can explain the lower summer biomass of Lumbrineris spp., as it was reported to release larvae in May-July (Fetzer and Arntz 2008). On the other hand, Oweniidae and Spionidae were reported to reproduce in spring/ summer time as well (Blake and Arnofsky 1999; Rouse and Pleijel 2001), but in the present study we noted higher biomass of G. oculata (owenid) and P. cirrifera (spionid) in summer. For $G$. oculata there were more small specimens in winter, which may indicate recruitment after our summer sampling (in fall or early winter). Obviously, the seasonality in particular species reproductive cycles results in some seasonal differences in the size distributions of their populations but these effects overlap and are not translated into a tractable pattern at the whole community level. Ambrose and Renaud (1997) did not find the consistent response in polychaete recruitment to seasonal input of labile organic matter after the spring bloom in the Northeast Water Polynya. Also the year-round recruitment without evident seasonal pulses of recruiters was noted in West Antarctic Peninsula and was explained by persistent food availability (Mincks and Smith 2007).

\section{Spatial variability in size spectra}

Benthic size spectra differed more among stations than between seasons. The stations in the present study were located in the central basin of the fjord, with low sedimentation and outside the bulk of local fluvial or glaciofluvial inflows and respective environmental gradients (WłodarskaKowalczuk et al. 2005). Still there was a clear trend of decreasing POC content moving into the fjord from KB1 to KB3 indicating decreasing impact of Atlantic waters and resulting decreases in primary production (Piwosz et al. 2009) and zooplankton fecal pellet supply (Lalande et al. 2016). Akoumianaki et al. (2006), in a study of deltaic macrofauna in the Mediterranean, found evidence of spatial differences in NBSS parameters-the decrease of slopes with growing distance from the river mouth. The decrease of NBSS slopes was also interpreted as a result of impoverished food supply with depth for benthic communities on the Antarctic shelf (Saiz-Salinas and Ramos 1999). In the present study we noted an increase of food availability and its freshness (indicated by increase of $\mathrm{Chl}$ a) from station KB3 to KB1, but these trends were not followed by similar changes in biomass or NBSS slopes. Other drivers of natural variability (e.g., near-bottom currents or bottom topography), possibly including biological synergies (e.g., adult-larva interactions or bioturbation) may play a crucial role in producing these spatial patterns (Ysebaert and 
Herman 2002; Norkko et al. 2013). Włodarska-Kowalczuk and Wesławski (2008) explored the scales of the spatial heterogeneity in the undisturbed outer basin of Hornsund fjord (similar to our study area) and reported distinct patches with varying species composition at a distance of $200 \mathrm{~m}$ that could not be explained by environmental heterogeneity.

In summary, the described size spectra of benthic communities in Kongsfjorden have similar shape to those reported from lower latitudes. Despite the seasonal changes in organic matter produced in the water column, as indicated by peaks in CPE concentration in the sediments, no difference in the community size structure between the seasons was noted. The differences in size distributions for dominant species were equivocal and not translated into a common trend visible at the community level. The summer-winter stability of size spectra in benthic communities (especially in fjord type ecosystem) further supports the hypothesis of 'food bank' in polar sediments and relative independence of polar benthic biota from the seasonality in the pelagic productivity. However, it must be noted that the present findings rely on results from a single fjord system, limited number of stations, and only two seasons; therefore it is recommended to test these ideas in other fjords and at the wider spatial and temporal scales like Arctic open waters or ice-edge zones.

Acknowledgements We wish to thank the crews of R/V Oceania and R/V Helmer Hansen for their help during sampling. We are also grateful to Dr. Loïc Michel and Dr Gilles Lepoint for the help in laboratory analysis of sediments. The article was prepared during doctoral studies conducted by MM at the Centre for Polar Studies, University of Silesia, Poland and the project has been financed from the funds of the Leading National Research Centre (KNOW) received by the Centre for Polar Studies for the period 2014-2018. This study was made possible by funding provided to IOPAN for the period 2013-2016 for co-funded international collaborative research based on contract no. 2930/Norway/2013/2, and funds from the Polish-Norwegian Research Programme operated by the National Centre for Research and Development under the Norwegian Financial Mechanism 2009-2014 in the frame of Project Contract No Pol-Nor/201992/93/2014 (DWARF). This work was also supported by funds from the Norwegian Research Council (Marine Night, NRC 226417).

\section{Compliance with ethical standards}

Conflict of interest The authors declare that they have no conflicts of interest.

Open Access This article is distributed under the terms of the Creative Commons Attribution 4.0 International License (http://creativeco mmons.org/licenses/by/4.0/), which permits unrestricted use, distribution, and reproduction in any medium, provided you give appropriate credit to the original author(s) and the source, provide a link to the Creative Commons license, and indicate if changes were made.

\section{References}

Akaike H (1974) A new look at the statistical model identification. IEEE Trans Automat Contr 19:716-723

Akoumianaki I, Papaspyrou S, Nicolaidou A (2006) Dynamics of macrofaunal body size in a deltaic environment. Mar Ecol Prog Ser 321:55-66. https://doi.org/10.3354/meps321055

Ambrose WG, Renaud PE (1997) Does a pulsed food supply to the benthos affect polychaete recruitment patterns in the Northeast Water Polynya? J Mar Syst 10:483-495. https://doi.org/10.1016/ S0924-7963(96)00053-X

Anderson MJ, Gorley RN, Clarke KR (2008) PERMANOVA for PRIMER: guide to software and statistical methods. PRIMER-E Ltd, Plymouth

Andrassy I (1956) The determination of volume and weight of nematodes. Acta Zool Acad Sci Hung 2:1-15

Berestovsky EG, Anisimova NA, Denisenko SG, Luppova EN, Savinov VM, Timofeev SF (1989) The relationship between the size and weight of some invertebrates and fish the North-East Atlantic. Publishing House of the KSC of the USSR Academy of Sciences, Apatity

Berge J, Daase M, Renaud PE et al (2015) Unexpected levels of biological activity during the polar night offer new perspectives on a warming Arctic. Curr Biol 25:2555-2561. https://doi. org/10.1016/j.cub.2015.08.024

Berge J, Renaud PE, Darnis G, Cottier F, Last K, Gabrielsen TM, Johnsen G, Seuthe L, Marcin J, Leu E, Moline M, Nahrgang J, Søreide JE, Varpe $\varnothing$, Jørgen O, Daase M, Falk-petersen S (2015) In the dark: a review of ecosystem processes during the Arctic polar night. Prog Oceanogr 139:258-271. https://doi.org/10.1016/j. pocean.2015.08.005

Binzer A, Guill C, Rall BC, Brose U (2016) Interactive effects of warming, eutrophication and size structure: impacts on biodiversity and food-web structure. Glob Chang Biol 22:220-227. https ://doi.org/10.1111/gcb.13086

Blake JA, Arnofsky PL (1999) Reproduction and larval development of the spioniform polychaete with application to systematics and phylogeny. Hydrobiologia 402:57-106

Boudreau PR, Dickie LM (1992) Biomass spectra of aquatic ecosystems in relation to fisheries yield. Can J Fish Aquat Sci 49:15281538. https://doi.org/10.1139/f92-169

Bourgeois S, Kerhervé P, Calleja ML, Many G, Morata N (2016) Glacier inputs influence organic matter composition and prokaryotic distribution in a high Arctic fjord (Kongsfjorden, Svalbard). J Mar Syst 164:112-127. https://doi.org/10.1016/j.jmarsys.2016.08.009

Brey T, Müller-Wiegmann C, Zittier ZMC, Hagen W (2010) Body composition in aquatic organisms - a global data bank of relationships between mass, elemental composition and energy content. $\mathrm{J}$ Sea Res 64:334-340. https://doi.org/10.1016/j.seares.2010.05.002

Chen J, Oseji O, Mitra M, Waguespack Y, Chen N (2016) Phytoplankton pigments in maryland coastal bay sediments as biomarkers of sources of organic matter to benthic community. J Coast Res 32:768-775. https://doi.org/10.2112/JCOASTRES-D-14-00223.1

Clarke KR, Gorley RN (2015) PRIMER v7: User Manual/Tutorial. PRIMER-E Ltd, Plymouth

Cooper LW, Grebmeier JM, Larsen IL, Egorov VG, Theodorakis C, Kelly HP, Lovvorn JR (2002) Seasonal variation in sedimentation of organic materials in the St. Lawrence Island polynya region. Bering Sea. Mar Ecol Prog Ser 226:13-26. https://doi. org/10.3354/meps226013

Cottier F, Tverberg V, Inall M, Svendsen H, Nilsen F, Griffiths C (2005) Water mass modification in an Arctic fjord through cross-shelf exchange: the seasonal hydrography of Kongsfjorden. Svalbard. J Geophys Res Ocean 110:C12005. https://doi.org/10.1029/2004J C002757 
Datta S, Blanchard JL (2016) The effects of seasonal processes on size spectrum dynamics. Can J Fish Aquat Sci 73:598-610. https://doi. org/10.1139/cjfas-2015-0468

De Kerckhove DT, Shuter BJ, Milne S (2016) Acoustically derived fish size spectra within a lake and the statistical power to detect environmental change. Can J Fish Aquat Sci 73:565-574. https:// doi.org/10.1139/cjfas-2015-0222

Drgas A, Radziejewska T, Warzocha J (1998) Biomass size spectra of near-shore shallow-water benthic communities in the Gulf of Gdansk (Southern Baltic Sea). Mar Ecol 19:209-228

Duplisea DE, Drgas A (1999) Sensitivity of a benthic, metazoan, biomass size spectrum to differences in sediment granulometry. Mar Ecol Prog Ser 177:73-81. https://doi.org/10.3354/meps1 77073

Echeverria CA, Paiva PC (2006) Macrofaunal shallow benthic communities along a discontinuous annual cycle at Admiralty Bay, King George Island, Antarctica. Polar Biol 29:263-269. https:// doi.org/10.1007/s00300-005-0049-6

Elton CS (1927) Animal ecology. Macmillan, New York

Evans C, O'Reilly JE (1983) A manual for the measurement of chlorophyll a, net phytoplankton, and nannoplankton: provisional copy for use on vessels participating in FIBEX. Scientific series, vol 9. BIOMASS, Grand Forks

Evans C, Reilly J, Thomas J (1987) A handbook for the measurement of chlorophyll-a and primary productivity. Texas A \& M University, Texas, College Station

Feller RJ, Warwick RM (1988) Energetics. In: Higgins RP, Thiel H (eds) Introduction to the Study of Meiofauna. Smithsonian Institution Press, Washington, D.C., pp 181-196

Fetzer I, Arntz WE (2008) Reproductive strategies of benthic invertebrates in the Kara Sea (Russian Arctic): adaptation of reproduction modes to cold water. Mar Ecol Prog Ser 356:189-202. https ://doi.org/10.3354/meps07271

Gaedke U (1992) The size distribution of plankton biomass in a large lake and its seasonal variability. Limnol Oceanogr 37:1202-1220. https://doi.org/10.4319/lo.1992.37.6.1202

García R, Thomsen L, de Stigter HC, Epping E, Soetaert K, Koning E, de Jesus Mendes PA (2010) Sediment bioavailable organic matter, deposition rates and mixing intensity in the Setúbal-Lisbon canyon and adjacent slope (Western Iberian Margin). Deep Res Part I Oceanogr Res Pap 57:1012-1026. https://doi.org/10.1016/j. dsr.2010.03.013

García-Comas C, Chang C-Y, Ye L, Sastri AR, Lee Y-C, Gong G-C, Hsieh C-H (2014) Mesozooplankton size structure in response to environmental conditions in the East China Sea: how much does size spectra theory fit empirical data of a dynamic coastal area? Prog Oceanogr 121:141-157. https://doi.org/10.1016/j.pocea n.2013.10.010

Glover AG, Smith CR, Mincks SL, Sumida PYG, Thurber AR (2008) Macrofaunal abundance and composition on the West Antarctic Peninsula continental shelf: evidence for a sediment "food bank" and similarities to deep-sea habitats. Deep Res Part II Top Stud Oceanogr 55:2491-2501. https://doi.org/10.1016/j. dsr2.2008.06.008

Gooday AJ (2002) Biological responses to seasonally varying fluxes of organic matter to the ocean floor: a review. J Oceanogr 58:305-332

Górska B, Włodarska-Kowalczuk M (2017) Food and disturbance effects on Arctic benthic biomass and production size spectra. Prog Oceanogr 152:50-61. https://doi.org/10.1016/j.pocea n.2017.02.005

Górska B, Gromisz S, Włodarska-Kowalczuk M (2019) Size assessment in polychaete worms - application of morphometric correlations for common North Atlantic taxa. Limnol Oceanogr Methods 17:254-265. https://doi.org/10.1002/lom3.10310
Graham NAJ, Dulvy NK, Jennings S, Polunin NVC (2005) Size-spectra as indicators of the effects of fishing on coral reef fish assemblages. Coral Reefs 24:118-124. https://doi.org/10.1007/s0033 8-004-0466-y

Hedges JI, Stern JH (1984) Carbon and nitrogen determinations of carbonate-containing solids. Limnol Oceanogr 29:657-663. https ://doi.org/10.4319/lo.1984.29.3.0657

Hegseth EN, Tverberg V (2013) Effect of Atlantic water inflow on timing of the phytoplankton spring bloom in a high Arctic fjord (Kongsfjorden, Svalbard). J Mar Syst 113-114:94-105. https:// doi.org/10.1016/j.jmarsys.2013.01.003

Heip C, Vincx M, Vranken G (1985) The ecology of marine nematodes. Oceanogr Mar Biol 23:399-489

Hillebrand H, Dürselen C-D, Kirschtel D, Pollingher U, Zohary T (1999) Biovolume calculation for palagic and benthic microalgae. J Phycol 35:403-424

Hodal H, Falk-Petersen S, Hop H, Kristiansen S, Reigstad M (2012) Spring bloom dynamics in Kongsfjorden, Svalbard: Nutrients, phytoplankton, protozoans and primary production. Polar Biol 35:191-203. https://doi.org/10.1007/s00300-011-1053-7

Hop H, Falk-Petersen S, Svendsen H, Kwasniewski S, Pavlov V, Pavlova O, Søreide JE (2006) Physical and biological characteristics of the pelagic system across Fram Strait to Kongsfjorden. Prog Oceanogr 71:182-231. https://doi.org/10.1016/j.pocea n.2006.09.007

Hua E, Zhang Z, Warwick RM, Deng K, Lin K, Wang R, Yu Z (2013) Pattern of benthic biomass size spectra from shallow waters in the East China Seas. Mar Biol 160:1723-1736. https://doi. org/10.1007/s00227-013-2224-6

Jennings S, Pinnegar JK, Polunin NVC, Warr KJ (2002) Linking sizebased and trophic analyses of benthic community structure. Mar Ecol Prog Ser 226:77-85. https://doi.org/10.3354/meps226077

Juul-Pedersen T, Arendt KE, Mortensen J, Blicher ME, Søgaard DH, Rysgaard S (2015) Seasonal and interannual phytoplankton production in a sub-Arctic tidewater outlet glacier fjord, SW Greenland. Mar Ecol Prog Ser 524:27-38. https://doi.org/10.3354/ meps 11174

Kędra M, Legeżyńska J, Walkusz W (2011) Shallow winter and summer macrofauna in a high Arctic fjord $\left(79^{\circ} \mathrm{N}\right.$, Spitsbergen). Mar Biodivers 41:425-439. https://doi.org/10.1007/s1252 6-010-0066-8

Kędra M, Kuliński K, Walkusz W, Legezyńska J (2012) The shallow benthic food web structure in the high Arctic does not follow seasonal changes in the surrounding environment. Estuar Coast Shelf Sci 114:183-191. https://doi.org/10.1016/j.ecss.2012.08.015

Kelly-Gerreyn BA, Martin AP, Bett BJ, Anderson TR, Kaariainen JI, Main CE, Marcinko CJ, Yool A (2014) Benthic biomass size spectra in shelf and deep-sea sediments. Biogeosciences 11:64016416. https://doi.org/10.5194/bg-11-6401-2014

Krajewska M, Szymczak-Żyła M, Kowalewska G (2017) Algal pigments in Hornsund (Svalbard) sediments as biomarkers of Arctic productivity and environmental conditions. Polish Polar Res 38:423-443. https://doi.org/10.1515/popore-2017-0025

Kukliński P, Berge J, McFadden L, Dmoch K, Zajączkowski M, Nygård H, Piwosz K, Tatarek A (2013) Seasonality of occurrence and recruitment of Arctic marine benthic invertebrate larvae in relation to environmental variables. Polar Biol 36:549-560. https:// doi.org/10.1007/s00300-012-1283-3

Lalande C, Moriceau B, Leynaert A, Morata N (2016) Spatial and temporal variability in export fluxes of biogenic matter in Kongsfjorden. Polar Biol 39:1725-1738. https://doi.org/10.1007/s0030 0-016-1903-4

Link H, Archambault P, Tamelander T, Renaud PE, Piepenburg D (2011) Spring-to-summer changes and regional variability of benthic processes in the western Canadian Arctic. Polar Biol 34:2025-2038. https://doi.org/10.1007/s00300-011-1046-6 
Loeng H, Brander K, Carmack E, Denisenko S, Drinkwater K, Hansen B, Kovacs K, Livingston P, McLaughlin F, Sakshaug E (2005) Marine Systems. In: Symon C, Arris L, Heal W (eds) Arctic cimate impact assessment. Cambridge University Press, Cambridge, pp 452-538

Mazurkiewicz M, Górska B, Jankowska E, Włodarska-Kowalczuk M (2016) Assessment of nematode biomass in marine sediments: a semi-automated image analysis method. Limnol Oceanogr Methods 14:816-827. https://doi.org/10.1002/lom3.10128

Mincks SL, Smith CR (2007) Recruitment patterns in Antarctic Peninsula shelf sediments: evidence of decoupling from seasonal phytodetritus pulses. Polar Biol 30:587-600. https://doi.org/10.1007/ s00300-006-0216-4

Mincks SL, Smith CR, DeMaster DJ (2005) Persistence of labile organic matter and microbial biomass in Antarctic shelf sediments: Evidence of a sediment "food bank". Mar Ecol Prog Ser 300:3-19. https://doi.org/10.3354/meps300003

Morata N, Michaud E, Włodarska-Kowalczuk M (2013) Impact of early food input on the Arctic benthos activities during the polar night. Polar Biol 38:99-114. https://doi.org/10.1007/s00300-013-1414-5

Norkko A, Villnäs A, Norkko J, Valanko S, Pilditch C (2013) Size matters: implications of the loss of large individuals for ecosystem function. Sci Rep 3:2646. https://doi.org/10.1038/srep02646

Noufal KK, Najeem S, Latha G, Venkatesan R (2017) Seasonal and long term evolution of oceanographic conditions based on yeararound observation in Kongsfjorden, Arctic Ocean. Polar Sci 11:1-10. https://doi.org/10.1016/j.polar.2016.11.001

Parsons TR (1969) The use of particle size spectra in determining the structure of a plankton community. J Oceanogr Soc Japan 25:172-181

Pawłowska J, Włodarska-Kowalczuk M, Zajączkowski M, Nygård H, Berge J (2011) Seasonal variability of meio- and macrobenthic standing stocks and diversity in an Arctic fjord (Adventfjorden, Spitsbergen). Polar Biol 34:833-845. https://doi.org/10.1007/ s00300-010-0940-7

Piwosz K, Walkusz W, Hapter R, Wieczorek P, Hop H, Wiktor J (2009) Comparison of productivity and phytoplankton in a warm (Kongsfjorden) and a cold (Hornsund) Spitsbergen fjord in midsummer 2002. Polar Biol 32:549-559. https://doi.org/10.1007/ s00300-008-0549-2

Platt T, Denman K (1977) Organisation in the pelagic ecosystem. Helgoländer wissenschaftliche Meeresuntersuchungen 30:575-581. https://doi.org/10.1007/BF02207862

Platt T, Denman K (1978) The structure of pelagic marine ecosystems. Rapp Proces-Verbaux des Reun Cons Int pour L'Exploration Sci la Mer 173:60-65

Quiroga E, Quiñones R, Palma M, Sellanes J, Gallardo VA, Gerdes D, Rowe G (2005) Biomass size-spectra of macrobenthic communities in the oxygen minimum zone off Chile. Estuar Coast Shelf Sci 62:217-231. https://doi.org/10.1016/j.ecss.2004.08.020

Quiroga E, Ortiz P, Gerdes D, Reid B, Villagran S, Quiñones R (2012) Organic enrichment and structure of macrobenthic communities in the glacial Baker Fjord, Northern Patagonia, Chile. J Mar Biol Assoc UK 92:73-83. https://doi.org/10.1017/S00253154110003 85

Quiroga E, Ortiz P, González-Saldías R, Reid B, Tapia F, Pérez-Santos I, Rebolledo L, Mansilla R, Pineda C, Cari I, Salinas N, Montiel A, Gerdes D (2016) Seasonal benthic patterns in a glacial Patagonian fjord: the role of suspended sediment and terrestrial organic matter. Mar Ecol Prog Ser 561:31-50. https://doi.org/10.3354/ meps 11903

R Core Team (2018) R: A language and environment for statistical computing

Renaud PE, Riedel A, Michel C, Morata N, Gosselin M, Juul-Pedersen T, Chiuchiolo A (2007) Seasonal variation in benthic community oxygen demand: a response to an ice algal bloom in the Beaufort Sea, Canadian Arctic? J Mar Syst 67:1-12. https://doi. org/10.1016/j.jmarsys.2006.07.006

Renaud PE, Morata N, Carroll ML, Denisenko SG, Reigstad M (2008) Pelagic-benthic coupling in the western Barents Sea: processes and time scales. Deep Res Part II Top Stud Oceanogr 55:23722380. https://doi.org/10.1016/j.dsr2.2008.05.017

Renaud PE, Løkken TS, Jørgensen LL, Berge J, Johnson BJ (2015) Macroalgal detritus and food-web subsidies along an Arctic ford depth-gradient. Front Mar Sci 2:1-15. https://doi.org/10.3389/ fmars.2015.00031

Rodriguez J, Mullin MM (1986) Relation between biomass and body weight of plankton in a steady state oceanic ecosystem. Limnol Oceanogr 31:361-370. https://doi.org/10.4319/lo.1986.31.2.0361

Rouse G, Pleijel F (2001) Polychaetes. Oxford University Press, Oxford Rysgaard S, Thamdrup B, Risgaard-Petersen N, Fossing H, Berg P, Christensen PB, Dalsgaard T (1998) Seasonal carbon and nutrient mineralization in a high-Arctic coastal marine sediment, Young Sound, Northeast Greenland. Mar Ecol Prog Ser 175:261-276. https://doi.org/10.3354/meps175261

Saiz-Salinas JI, Ramos A (1999) Biomass size-spectra of macrobenthic assemblages along water depth in Antarctica. Mar Ecol Prog Ser 178:221-227. https://doi.org/10.3354/meps178221

Schewe I, Soltwedel T (2003) Benthic response to ice-edge-induced particle flux in the Arctic Ocean. Polar Biol 23:610-620. https:// doi.org/10.1007/s00300-003-0526-8

Schwinghamer P (1981) Characteristic size distributions of integral benthic communities. Can J Fish Aquat Sci 38:1255-1263. https ://doi.org/10.1139/f81-167

Sheldon RW, Prakash A, Sutcliffe WH (1972) The size distribution of particles in the ocean. Limnol Oceanogr 17:327-340. https://doi. org/10.4319/lo.1972.17.3.0327

Shunatova N, Nikishina D, Ivanov M, Berge J, Renaud PE, Ivanova T, Granovitch A (2018) The longer the better: the effect of substrate on sessile biota in Arctic kelp forests. Polar Biol 41:993-1011. https://doi.org/10.1007/s00300-018-2263-z

Soltwedel T, Mokievsky V, Schewe I (2000) Benthic activity and biomass on the Yermak Plateau and in adjacent deep-sea regions northwest of Svalbard. Deep Res Part I Oceanogr Res Pap 47:1761-1785. https://doi.org/10.1016/S0967-0637(00)00006-6

Sprules WG, Barth LE (2016) Surfing the biomass size spectrum: some remarks on history, theory, and application. Can J Fish Aquat Sci 73:477-495. https://doi.org/10.1139/cjfas-2015-0115

Sprules WG, Goyke AP (1994) Size-based structure and production in the pelagia of lakes Ontario and Michigan. Can J Fish Aquat Sci 51:2603-2611. https://doi.org/10.1139/f94-260

Sprules WG, Munawar M (1986) Plankton size spectra in relation to ecosystem productivity, size, and perturbation. Can J Fish Aquat Sci 43:1789-1794. https://doi.org/10.1139/f86-222

Stübner EI, Søreide JE, Reigstad M, Marquardt M, BłachowiakSamołyk K (2016) Year-round meroplankton dynamics in high-Arctic Svalbard. J Plankton Res 38:522-536. https://doi. org/10.1093/plankt/fbv124

Svendsen H, Beszczyńska-Møller A, Hagen JO, Lefauconnier B, Tverberg V, Gerland S, Ørbæk JB, Bischof K, Papucci C, Zajaczkowski M, Azzolini R, Bruland O, Wiencke C, Winther J-G, Dallmann W (2002) The physical environment of Kongsfjorden-Krossfjorden, an Arctic fjord system in Svalbard. Polar Res 21:133-166. https:// doi.org/10.1111/j.1751-8369.2002.tb00072.x

Trebilco R, Baum JK, Salomon AK, Dulvy NK (2013) Ecosystem ecology: size-based constraints on the pyramids of life. Trends Ecol Evol 28:423-431. https://doi.org/10.1016/j.tree.2013.03.008

Verity PG, Wassmann P, Frischer ME, Howard-Jones MH, Allen AE (2002) Grazing of phytoplankton by microzooplankton in the 
Barents Sea during early summer. J Mar Syst 38:109-123. https ://doi.org/10.1016/S0924-7963(02)00172-0

Warwick RM (2014) Meiobenthos and macrobenthos are discrete entities and not artefacts of sampling a size continuum: comment on Bett (2013). Mar Ecol Prog Ser 505:295-298. https://doi. org/10.3354/meps 10830

Warwick RM, Clarke KR (1984) Species size distributions in marine benthic communities. Oecologia 61:32-41. https://doi. org/10.1007/BF00379085

Wiencke C, Hop H (2016) Ecosystem Kongsfjorden: new views after more than a decade of research. Polar Biol 39:1679-1687. https ://doi.org/10.1007/s00300-016-2032-9

Włodarska-Kowalczuk M, Węsławski JM (2008) Mesoscale spatial structures of soft-bottom macrozoobenthos communities: effects of physical control and impoverishment. Mar Ecol Prog Ser 356:215-224. https://doi.org/10.3354/meps07285

Włodarska-Kowalczuk M, Pearson T, Kendall M (2005) Benthic response to chronic natural physical disturbance by glacial sedimentation in an Arctic fjord. Mar Ecol Prog Ser 303:31-41. https ://doi.org/10.3354/meps303031

Włodarska-Kowalczuk M, Górska B, Deja K, Morata N (2016) Do benthic meiofaunal and macrofaunal communities respond to seasonality in pelagial processes in an Arctic fjord (Kongsfjorden, Spitsbergen)? Polar Biol 39:2115-2129. https://doi.org/10.1007/ s00300-016-1982-2

Woelfel J, Schumann R, Peine F, Flohr A, Kruss A, Tegowski J, Blondel P, Wiencke C, Karsten U (2010) Microphytobenthos of Arctic Kongsfjorden (Svalbard, Norway): biomass and potential primary production along the shore line. Polar Biol 33:1239-1253. https:// doi.org/10.1007/s00300-010-0813-0
Ysebaert T, Herman PMJ (2002) Spatial and temporal variation in benthic macrofauna and relationships with environmental variables in an estuarine, intertidal soft-sediment environment. Mar Ecol Prog Ser 244:105-124. https://doi.org/10.3354/meps244105

Yurista PM, Yule DL, Balge M, VanAlstine JD, Thompson JA, Gamble AE, Hrabik TR, Kelly JR, Stockwell JD, Vinson MR (2014) A new look at the Lake Superior biomass size spectrum. Can J Fish Aquat Sci 71:1324-1333. https://doi.org/10.1139/cjfas-2013-0596

Zajączkowski M, Nygård H, Hegseth EN, Berge J (2010) Vertical flux of particulate matter in an Arctic fjord: the case of lack of the seaice cover in Adventfjorden 2006-2007. Polar Biol 33:223-239. https://doi.org/10.1007/s00300-009-0699-x

Zhou M (2006) What determines the slope of a plankton biomass spectrum? J Plankton Res 28:437-448. https://doi.org/10.1093/plank t/fbi119

Zhou M, Zhu Y, Peterson JO (2004) In situ growth and mortality of mesozooplankton during the austral fall and winter in Marguerite Bay and its vicinity. Deep Res Part II Top Stud Oceanogr 51:2099-2118. https://doi.org/10.1016/j.dsr2.2004.07.008

Zhou H, Zhang ZN, Liu XS, Tu LH, Yu ZS (2007) Changes in the shelf macrobenthic community over large temporal and spatial scales in the Bohai Sea, China. J Mar Syst 67:312-321. https:// doi.org/10.1016/j.jmarsys.2006.04.018

Publisher's Note Springer Nature remains neutral with regard to jurisdictional claims in published maps and institutional affiliations. 